\title{
ORIGINAL \\ PROF-1015 \\ SERUM SIALIC ACID CONCENTRATION AND TYPE II DIABETES MELLITUS
}

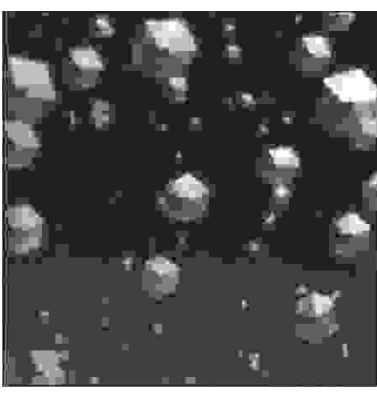

\author{
DR. MOHAMMAD JAWAID SABZWARI \\ M.B., B.S., M.Phil, \\ Assistant Professor (Chemical Pathology), \\ Institute of Nursing and Health Sciences, \\ Shaikh Zayed Medical Complex, Lahore.

\section{DR. MUHAMMAD TAHIR MAJEED} \\ M.B.B.S, M.Phil., \\ Postgraduate Student (PhD), \\ Microbiology Department, Federal \\ Postgraduate Medical Institute, \\ Shaikh Zayed Medical Complex, Lahore.
}

DR. MUKHTAR AHMAD,

M.B., B.S., M.Phil. Ex.

Assistant Professor of Biochemistry, Quaid-i-Azam Medical College, Bahawalpur.

Dr. Muhammad Riaz, M.B., B.S

Fatima Memorial Medical and Dental College, Shadman, Lahore.

\section{Mr. Muhammad Umair \\ 3rd Year M.B.B.S Student}

Fatima Memorial Medical and Dental College, Shadman, Lahore.

\begin{abstract}
Sialic Acid (SA) is an acetylated product of neuraminic acid. In present study, the relationship between sialic acid and type II diabetic patients was investigated. Ninety (90) subjects, 41 males and 49 females, were included in the study. They were divided into two groups according to presence or absence of type II diabetes mellitus (DM). Group A comprised of 72 patients with type II DM and group B 18 subjects without diabetes mellitus as a control group. The following parameters were assessed: sialic acid, blood glucose, lipid profile (serum triglycerides and total cholesterol) and HbA1c. Type II DM Patients had higher levels $(P<0.05)$ of sialic acid $(2.259 \pm 0.252 \mathrm{mmol} / \mathrm{L})$ as compared to the control group $(2.048 \pm 0.32 \mathrm{mmol} / \mathrm{L})$.
\end{abstract}

Key words: $\quad$ Sialic acid, Type II diabetes mellitus, Blood glucose.

\section{INTRODUCTION}

Sialic Acid (SA), a generic term for a family of acetylated derivatives of neuraminic acid, is an essential component of glyco-proteins and glycolipids ${ }^{1}$. It acts as a cofactor of many cell surface receptors (e.g. insulin receptors) ${ }^{2}$, and is positively associate with most of the serum acute phase reactants ${ }^{3,4}$. The levels of SA are increased in several pathologic states such as inflammation and malignancy ${ }^{4}$. In patients with type II Diabetes Mellitus (DM) the levels of sialic acid are increased ${ }^{5}$.

In present study, the relationship of SA was assessed in patients with type II diabetes mellitus (DM). 


\section{PATIENTS AND METHODS}

The study included 90 subjects, 41 males and 49 females. Diabetic patients were defined as those who had known diabetes (onset of DM after 40 years of age), and those with fasting plasma glucose value exceeding $7.8 \mathrm{mmol} / \mathrm{L}$ on two occasions.

According to presence or absence of type II DM, the subjects were divides into two groups: group $A, 72$ type II DM patients (32 males and 40 females) and group $B$, 18 subjects without DM ( 9 males and 9 females) as a control group. All group B subjects underwent oral glucose tolerance test (OGTT) to exclude the presence of impaired glucose tolerance (IGT), according to WHO criteria.

After over night fasting, venous blood samples for blood glucose, lipid profile and sialic acid estimation were obtained by venipuncture from an anticubital vein without stasis. Serum total SA was assessed using enzymatic method from Boehringer Mannheim. The method uses a coupled enzyme assay reaction incorporating neuraminidase, $\mathrm{N}$-acetyl neuraminic acid, aldolase and pyruvate oxidase linked to a peroxidase dye system. The blood glucose, total cholesterol and triglycerides were determined by using auto-analyzer, while HbAlc by using kit.

\section{RESULTS}

Table I shows biochemical characteristics of groups $A$ and $B$ related to number, sex, age and duration of diabetes mellitus. Group A and B were comparable according to age (mean age $61.60 \pm 7.2$ vs. $60.8 \pm 9.1$ years $p=$ [non significant] NS), duration of DM 12.3 \pm 2.45 years, $p=N S$ ).

Group A (diabetic patients) had higher plasma levels of total cholesterol and triglycerides $(p<0.05)$ in comparison with control subjects. The diabetic patients, whether males/females, had higher plasma levels $(p<0.05)$ of $S A$ $(2.259 \pm 0.252 \mathrm{mmol} / \mathrm{L})$ in comparison with controls $(2.048 \pm 0.32 \mathrm{mmol} / \mathrm{L})$. The comparison is also illustrated in Fig 1.

\begin{tabular}{|l|c|c|}
\hline \multicolumn{3}{|c|}{ Table-I. } \\
\hline Parameter & $\begin{array}{c}\text { Group A } \\
\text { (Type Il diabetic ps) }\end{array}$ & $\begin{array}{c}\text { Group B } \\
\text { (Control) }\end{array}$ \\
\hline $\mathrm{n}$ & 72 & 18 \\
\hline Sex (M/F) & $41 / 49$ & $9 / 9$ \\
\hline Age range (yrs) & $45-76$ & $47-71$ \\
\hline Age: Mean \pm SD & $61.6 \pm 7.2$ & $60.8 \pm 9.1$ \\
\hline $\begin{array}{l}\text { Duration of M } \\
\text { Range (yrs) }\end{array}$ & $5-25$ & - \\
\hline $\begin{array}{l}\text { Duration of DM } \\
\text { (Mean } \pm \text { SD) }\end{array}$ & $12.3 \pm 2.45$ & - \\
\hline \multicolumn{2}{|c|}{ There is no significant difference between these parameters } \\
\hline
\end{tabular}

Table-ll. shows comparison between diabetic patients and normal (control) subjects.

\begin{tabular}{|l|c|c|}
\hline Parameter & $\begin{array}{c}\text { Group A } \\
\text { (Type Il diabetic ps) }\end{array}$ & $\begin{array}{c}\text { Group B } \\
\text { (Control) }\end{array}$ \\
\hline Sialic acid (mmol/l & $2.259 \pm 0.252$ & $2.048 \pm 0.32$ \\
\hline HbAlc (g/dl) & $9.5 \pm 1.8$ & - \\
\hline $\begin{array}{l}\text { Total cholesterol } \\
\text { (mmol/l) }\end{array}$ & $6.38 \pm 0.55^{*}$ & $5.55 \pm 0.36$ \\
\hline $\begin{array}{l}\text { Triglycerides } \\
\text { (mmol/l) }\end{array}$ & $2.00 \pm 0.16^{*}$ & $1.84 \pm 0.09$ \\
\hline \multicolumn{2}{|c|}{ Value are presented as mean $\pm S D:{ }^{*}=p<0.05$} \\
for group A and $B$.
\end{tabular}

\section{DISCUSSION}

The results of our study show increased serum SA concentration $(p<0.05)$ in diabetic patients, especially the type 2 diabetics, as compared to normal control subjects. Furthermore, the serum SA levels were independents of the duration of DM and degree of metabolic control (as estimated by HBA1c). There was also a strong positive correlation observed between SA and important risk factors for diabetes mellitus such as total cholestrol and triglycerides. It has also been reported else where that $\mathrm{SA}$ is elevated in subjects with type 2 diabetes mellitus 
with out late complications, a finding which has not been recorded in type 1 diabetes mellitus patients ${ }^{5}$.

Fig-1. Sialic acid levels in group A and B

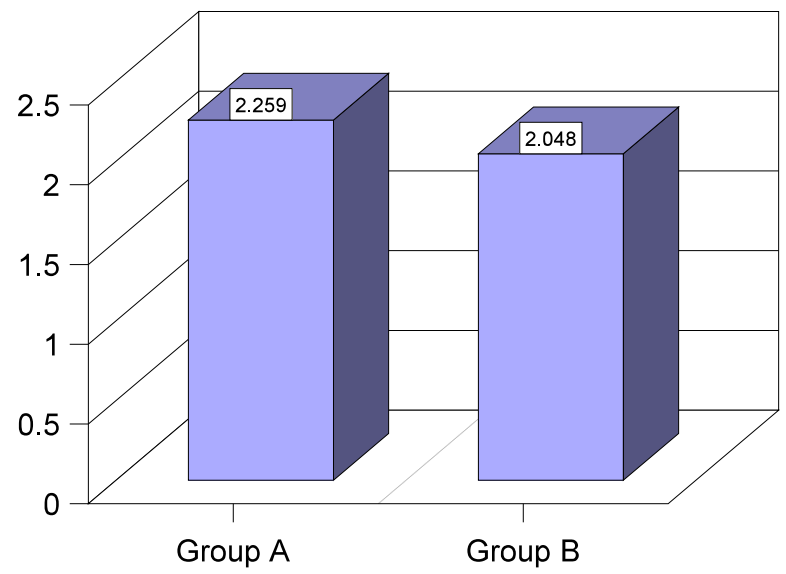

Besides this, serum SA levels are increased in type 1 diabetes mellitus patients with albuminuria ${ }^{6}$, independent of the degree of metabolic control. SA is also increased in non-diabetic patients with end stage renal disease ${ }^{7,8}$. The possible explanation of our findings, confirming the results of other authors ${ }^{9,10,11}$, is that this must be associated with the role of $S A$ in maintaining the negative charge of renal glomerular basement membrane, one of the main regulators of glomerular permeability $^{12}$. It may be speculated that vascular permeability is regulated by sialic acid moieties, with increased vascular permeability resulting from the shedding of vascular endothelial SA into circulation. As the majority of serum SA is a component of glycoprotein such as acute phase proteins $s^{3,4}$, it is important that several serum acute phase proteins are elevated in diabetics.

\section{REFERENCES}

1. Schauer R. Sialic acids. Trends Biochem 1985;7:357360 .
2. Salhanide AI, Amatruda JM. Role of sialic acid in insulin activity and the insulin resistance of diabetes mellitus. Am I Physiol 1988;255:E173-E179.

3. Pick up JC, Crook MA. Is type II diabetes mellitus a disease of innate immune system ? Diabetolgia 1999; 42(4):497-8.

4. Lucy M, Susan A. Nutritional Influences on inflammation and type II diabetes mellitus. Diabetes technology and therapeutic 2006; 8:45-54.

5. Merat A Arabsolghar R. Zamani J. Roozitalab M. Serum levels of sialic acid and neuraminidase activity in cardiovascular system, diabetic and diabetic retinopathy patients. Iran J Med Science 2003 25(3):123-126.

6. Shivananda N, Geetha BH. Relationship between sialic and acid and metabolic variables in indiane diabetic patients. Lipids in health \& disease 2005; 4: 15.

7. Powie JK, Watts GF, Crook MA, Ingham JN, Shaw KM. Serum sialic acid and the long term complications of insulin dependent diabetes mellitus. Diabet Med 1996;13:238-242.

8. Chen J, Gall MA, Yokoyama H, Jensen JS. Raised serum sialic acid conc. In NIDDM patient with \& without nephropathy. Diabetes care 1996; 19: 130-134.

9. Abdella M, Akanji A, Mojminiyi OA, Al Assoussi A, Mousa $M$. Relation of serum total sialic acid conc. With diabetic complications \& cardiovascular risk factors in Kuwati type II diabetic patients. Diabetes Res Clin Pract 2000; 50(1):65-72.

10. Crook MA, Serum sialic acid, and its relevance to diabetes mellitus. Endocrinol Metab 1996; 3: 207-213.

11. Suzuki K, Ishida $H$, Sugimoto $C$, Taguchi $Y$, Matsuda $H$, Nosaka K, Someya Y, Kadowaki S, Seino Y. The urinary concentration of sialic acid is increased in NIDDM with microangiopathy. A possible useful marker for diabetic microangiopathy. Diabet Med 1995; 12: 1092-1097.

12. Tomino Y, Inoue W, Watannable S, Yagame M, Eguchi K, Nomoto Y, Sakai H. Detection of glomerular sialic acid in patients with diabetic nephropathy. Am J Nephrol 1988;8:21-26. 